\title{
SEJARAH ETNOPEDAGOGI PADA MASYARAKAT MORONENE DI KELURAHAN TAUBONTO KECAMATAN RAROWATU KABUPATEN BOMBANA ${ }^{1}$
}

\section{HISTORY OF ETNOPEDAGOGY IN MORONENE COMMUNITIES IN KELURAHAN TAUBONTO, RAROWATU DISTRICT, BOMBANA REGENCY ${ }^{l}$}

\author{
Anggi Puspita Sari Dewi Ningsi ${ }^{2}$ \\ Email: anggipuspistasrd@gmail.com
}

\author{
Hj. Darnawati ${ }^{3}$ \\ email:darnawati@uho.ac.id
}

\section{${ }^{1)}$ Hasil Penelitian Tahun 2018, ${ }^{2)}$ Alumni Jurusan Pendidikan Sejarah, ${ }^{3)}$ Dosen FKIP UHO}

ABSTRAK: Tujuan utama dalam penelitian ini adalah: (1) Untuk mendeskripsikan latar belakang etnopedagogi pada masyarakat Moronene di Kelurahan Taubonto, (2) Untuk mendeskripsikan implementasi etnopedagogi dalam lingkungan keluarga masyarakat Moronene di lingkungan sekitarnya, (3) Untuk mendeskripsikan karakter yang dikembangkan etnopedagogi dalam budaya masyarakat Moronene. Prosedur penelitian ini terdiri atas 3 tahap yaitu: (1) Heuristik, yang terdiri dari a) penelitian kepustakaan, b) pengamatan, c) wawancara (2) Kritik sumber, yang terdiri dari a) kritik eksternal b) kritik internal dan (3) Historiografi, yang terdiri dari a) penafsiran (interpretasi), b) penjelasan (eksplanasi), dan c) penyajian (ekspose). Hasil penelitian menunjukan bahwa: (1) Latar belakang etnopedagogi pada Masyarakat Moronene, etnopedagogi merupakan landasan dalam pendidikan sejalan dengan salah satu landasan filosofi pengembangan pendidikan yang berakar pada budaya bangsa masa kini dan masa yang akan datang. (2) Implementasi etnopedagogi dalam lingkungan keluarga masyarakat Moronene yaitu: a) Pendidikan dalam bidang agama, dalam hal agama suku Moronene mayoritas memeluk agama islam, adapun ajaran agama yang diberikan pada anaknya yaitu mengaji, sholat, menghafal ayatayat Al-Quran. b) Pendidikan dalam bidang bertata krama, dalam budaya masyarakat Moronene ada yang disebut Moko Anu dan Upalli, inilah yang membangun semangat manusia ketika ia pergi untuk menuntut ilmu maupun bekerja. c) Pendidikan dalam bidang bertutur kata, bertutur kata adalah sesuatu yang kita ucapakan dengan baik dan santun yang mencerminkan tingkah laku yang baik. dan d) Pendidikan bidang sosial agar memahami norma-norma yang ada dalam keluarga maupun dalam masyarakat. (3) Karakter yang dikembangkan pada etnopedagogi dalam budaya masyarakat Moronene yaitu: 1) Kejujuran, dimana anak sejak kecil sudah mulai diajarkan jujur kepada orang tuanya. 2) Disiplin, anak sejak masih kecil sudah mulai di ajarkan disiplin waktu agar kelak dewasa nanti ia bias lebih dispilin lagi dalam hal apa saja.. 3) Kemandirian, anak diajarkan mandiri agar kelak ia dapat mengurus dirinya sendiri tidak bergantung pada orang lain lagi. 4) Demokratis, ini ditandai dengan adanya sikap terbuka antara orang tua dan anaknya, mereka membuat aturan-aturan yang di setujui bersama. dan 5) Tanggung jawab, tanggung jawab keluarga merupakan pusat pendidikan yang tidak hanya menyelenggarakan pendidikan diri dan sosial saja.

Kata Kunci: Latar Belakang, Implentasi, Etnopedagi, Karakter

ABSTRACT: The main objectives in this study are: (1) To describe the ethnopedagogical background of the Moronene community in the Taubonto Village, (2) To describe the implementation of ethno-agogy in the family environment of the Moronene community in the surrounding environment, (3) To describe the character developed by the ethnopedagogist in Moronene community culture. This research procedure consists of 3 stages, namely: (1) Heuristics, which consists of a) library research, b) observations, c) interviews (2) Critical sources, which consist of a) external criticism b) internal criticism and (3) Historiography, which consists of a) interpretation (interpretation), b) explanation (explanation), and c) presentation (exposure). The results showed that: (1) Ethnopedagogical background in the Moronene Society, ethnopedagogy is the foundation in education in line with one of the philosophical foundations of educational 
E-ISSN: 2502-6674

P-ISSN: 2502-6666

http://ojs.uho.ac.id/index.php/p_sejarah_uho

development that is rooted in the nation's culture today and in the future. (2) Implementation of ethnopedagogy in the Moronene community family environment, namely: a) Education in the field of religion, in terms of the majority Moronene religion embraces Islam, as for the religious teachings given to their children namely to recite, pray, memorize verses of the Koran. b) Education in the field of manners, in the culture of the Moronene community there is what is called Moko Anu and Upalli, this is what builds human enthusiasm when he goes to study and work. c) Education in the field of word-telling, word-telling is something that we say well and politely that reflects good behavior. and d) Social education in order to understand the norms that exist in the family and in the community. (3) The characters developed in ethnopedagogy in the culture of the Moronene community are: 1) Honesty, where children from childhood have begun to be taught honestly to their parents. 2) Discipline, children from childhood have begun to be taught the discipline of time so that later they can later be more disciplined in any case .. 3) Independence, children are taught independently so that one day they can take care of themselves not to depend on others anymore. 4) Democratic, this is marked by the open attitude between parents and children, they make rules that are agreed upon together. and 5) Responsibilities, family responsibilities are the center of education which does not only carry out self and social education.

Keywords: Background, Implementation, Ethnopedagi, Character

\section{PENDAHULUAN}

Derasnya arus globalisasi mengakibatkan terkikisnya budaya masyarakat dan kebudayaan lokal sehingga kebudayaan lokal yang merupakan warisan leluhur terinjak-injak oleh budaya asing dan terlupakan oleh pewarisnya, bahkan banyak remaja yang tidak mengenali budaya daerahnya. Mereka cenderung lebih bangga dengan karya-karya asing dan gaya hidup kebarat-baratan dibandingkan dengan budaya sendiri. Lembaga keluarga merupakan lembaga pendidikan pertama dan utama yang perlu mendapatkan perhatian. Sebab lingkungan keluarga sebagai jembatan antara individu dan kebudayaannya, agar nilai-nilai, norma-norma, adat-istiadat, tetap terjaga dan tetap langgeng dan dianut oleh generasi ke generasi, melalui keluarga, anak belajar mengenai nilai, peran sosial, norma dan adat istiadat yang ditanamkan oleh orang tuanya melalui kasih sayang.

Menurut Tamburaka (1993: 5) bahwa sejarah adalah catatan tentang masyarakat umat manusia atau peradaban dunia tentang perubahan yang terjadi pada waktu manusia seperti: keliaran, kerahmataman dan solidaritas golongan ini kian mencapai kehidupannya maupun dalam bermacam-macam ilmu pengetahuan dan pada umumnya tentang segala perubahahan yang terjadi di dalam masyarakat karena waktak itu sendiri. Sejarah sebagai suatu kajian tentang aktivitas manusia pada masa lampau, baik dibidang politik, militer, sosial, agama, ilmu pengetahuan, dan hasil kreatiitas seni. Definisi ini cenderung menempatkan sejarah sebagai kajian terhadap peristiwaperistiwa yang terjadi pada masa lampau. Peristiwa sejarah tidak bisa berdiri sendiri, dalam arti lepas dari elemen-elemen yang terjadi persyaratan terbentuknya suatu peristiwa sejarah. Aspek yang terkait dengan peristiwa sejarah, aspek peristiwa itu sendiri, aspek ruang, aspek waktu, perubahan, dan kesinambungan (Arif, 2011: 7)

Menurut Kartodirdjo (2017: 16) yang membagi sejarah menjadi dua yaitu sejarah dalam arti subyektif adalah suatu uraian atau cerita dan sejarah dalam arti obyektif merujuk kepada kejadian atau peristiwa itu sendiri, ialah proses sejarah aktualitasnya. Sejarah menurut bahasa terbagi dua yaitu pengertian sejarah dalam arti sempit dan dalam arti luas. Dalam arti sempit, pengertian sejarah ialah kejadian atau peristiwa. Sedangkan dalam arti luas ialah suatu peristiwa manusia yang memiliki akar dalam realisasi diri dengan kebebasan dan keputusan daya rohani.

Pendidikan merupakan salah satu kebutuhan pokok dalam kehidupan manusia yang berpikir bagaimana menjalani kehidupan dunia ini dalam rngka mempertahankan hidup dalam hidup dan penghidupan manusia yang mengembangkan tugas dari sang khalik untuk beribada. Pendidikan adalah sebuah pandangan atau rangkaian pendapat tentang pendidikan yang disajikan dalam sebuah sistem konsep. Pendidikan sebagai sistem mengandung arti suatu kelompok tertentu setidaknya memiliki hubungan khusus secara timbal balik dan memiliki informasi (Sunny, 2013: 3) 
Berdasarkan UU Sisdiknas No 20 Tahun 2003, bahwa pendidikan adalah usaha sadar dan terencana untuk mewujudkan suasana belajar dan proses pembelajaran ajar peserta didik secara aktif mengembangkan potensi dirinya untuk memiliki kekuatan spiritual keagamaan, pengendalian diri, kepribadian, kecerdasaan, ahlak mulia, serta keterampilan yang diperlukan dirinya, masyarakat, bangsa dan negara. Pendidikan dalam arti yang luas memiliki tiga pengertian, yaitu mendidik, mengajar, dan melatih. Mendidik memiliki pengertian menunjukan usaha yang lebih ditujukan kepada pengembangan budi pekerti, semangat, kecintaan, rasa kesusilaan, dan ketakwaan. Mengajar memiliki pengertian memberi pelajaraan tentang berbagai ilmu yang bermanfaat bagi perkembangan intelektual. Sedangkan melatih memiliki pengertian suatu usaha untuk memberi sejumlah keterampilan tertentu, yang dilakukan scara berulang-ulang, sehingga akan terjadi suatu pembiasaan dalam tindakan (Salam, 2002: 5).

Perkembangan emosi adalah setiap kegiatan atau pengelolaan pikiran, perasaan, dan nafsu setiap keadaan mental yang hebat dan meluap-luap. Emosi dapat terbentuk karena adanya komponen kognitif, komponen fisikos dan komponen perilaku, komponen kognitif termasuk perasaan subjektif memiliki aspek-aspek evaluasi. Emosi seseorang akan berjalan sesuai dengan pertumbuhan usia, pada masa awal anak dilihat dari segi emosionalnya masih bersifat egosentris pada saat tertentu anak ingin mengekspresikan emosinya dan perlu mendapat perhatian yang tepat. Emosi anak akan berkembang, apabila anak mendapat bimbingan secara tepat dengan penuh kasih sayang dan keadaan fisik serta lingkungan mendukung perkembangan emosi anak.

Pendidikan dapat diartikan sebagai suatu hasil peradaban bangsa yang dikembangkan atas dasar pandangan hidup bangsa itu sendiri (nilai dan norma masyarakat) yang berfungsi sebagai filsafat pendidikannya, bagaimanapun peradabaan suatu masyarakat, didalamnya terjadi suatu proses pendidikan sebagai usaha manusia untuk melestarikan dan mengembangkan hidupnya (Hafid, 2013: 27). Pendidikan adalah upaya sadar yang diarahkan untuk mencapai perbaikan di segala aspek kehidupan manusia (Rohman, 3013: 8). Pendidikan harus dilihat di dalam cakupan pengertian yang luas. Pedidikan juga bukan merupakan suatu proses yang netral sehingga terbebas dari nilai-nilai dan ideologi. Djahiri menyatakan bahwa pendidikan adalah merupakan upaya yang terorganisir, terencana dan berlangung kontinyu (terus menerus sepanjang hayat) kearah membina manusia/ anaka didik menjai insan paripurna, dewasa dan berbudaya (civilizet) (Hafid, 2014: 56$57)$.

Etnopeagogi adalah praktek pendidikan berbasis kearifan lokal dalam berbagai ranah seperti pengobatan, seni bela ddiri, lingkungan hidup, pertanian, ekonomi, pemerintah, sistem penaggalan, dan lain-lain (Nawili, 2015: 14). Etnopedagogoi memandang pengetahuan atau kearifan lokal sebagai sumber inovasi dan keterampilan yang dapat diberdayakan demi kesejatraan masyarakat. Kearifan lokal adalah koleksi fakta, konsep keperayaan, dan presepsi masyarakat ihwal dunia akhirat, menyelesaikan masalah, dan memalidasi informasi. Kearifan lokal adalah bagaimana pengetahuan dihasilkan, simpan, diterapkan, dikelolah dan diwriskan. Etnopedagogi merupakan praktik pendidikan berbasis kearifan lokal dan bersumber dari nilai-nilai kultural suatu etnis dan menjadi standar perilaku (Rustam, 2014:14). Etnopedagogi merupakan landasan dalam pendidikan sebagaimana sejalan dengan salah satu landasan filosofi pengembangan kurikulum 2013 yaitu pendidikan berakar pada budaya bangsa masa kini dan masa yang akan datang (permen No. 9 tahun 2013).

Nilai-nilai, konsep dan muatan pendidikan berbasis etnopedagogi yang layak diekplorasi, diinterpretasi, direvitalisasi dan dikembangkan sebagai konsep-konsep dan model-model etnopedagogi dalam pendidikan maupun pembelajaran. Mengingat nilai-nilai yang terkandung dalam etnopedagogi begitu besar dan bermakna bagi kesinambungan pembangunan karakter bangsa, maka pentinguntuk dilestarikan secara berkelanjutan terutama melalui tradisi (pembiasaan) penulisaan sejarah lokal (Hafid, 2017: 105-107).

Masyarakat di Indonesia terdiri dari berbagai suku, agama, ras, dan bangsa yang memiliki latar belakang yang berbeda-beda baik dari segi kultur, letak geografis, maupun sikap ari masing- 
masing individu. Oleh karena itu, masyarakat indonesia tetap memiliki hak dan kewajiban yang sama sebagai warga Negara Indonesia, yang dituntut untuk selalu bersatu tanpa mempedulikan berbagai perbedaan yang ada demi menjaga keutuhan Negara Republik Indonesia.

Menurut Syahrial (2009: 7) bahwa masyarakat adalah sejumlah manusia yang hidup dalam suatu lingkungan, dalam kurun waktu yang cukup lama sehingga melahirkan budaya dengan satu kesatuan kriteria dalam memiliki sistem hidup bersama. Masyarakat merupakan kelompok atau konektivitas manusia yang melakukan hubungan antara satu dan yang lain secara berkesinambungan dan memiliki karakteristik tertentu yang bersifat kekal. Relasi manusia sebagai suatu masyarakat, tidak terjadi dalam kurun waktu yang singkat, melainkan dalam waktu yang relatif cukup lama ( Setiadi, dkk. 2009: 82).

Nilai adalah adanya suatu perbedaan penyusunan antara apa yang dibutuhkan dan diinginkan. Nilai-nilai tersusun secara organisasi dan mengatur rangsangan kepuasan hati dalam mencapai tujuan kepribadiannya (Munandar, 1989: 19). Selanjutnya Pelly (1994: 14) mengemukakan bahwa nilai merupakan sesuatu yang abstrak, yang dijadikan pedoman serta prinsip-prinsip umum dalam bertindak dan bertingkah laku. Keterkaitan orang atau kelompok terhadap nilai relatif sangat kuat bahkan bersifat emosional. Oleh sebab itu, nilai dapat dilihat sebagai tujuan kehidupan manusia itu sendiri.

Hal ini yang sama dituangkan oleh Kemandiknas yang akan ditanamkan dalam diri peserta didik sebagai upaya membangun karakter bangsa dengan kata lain peserta didik dituntut untuk dapat merubah perilaku yang buruk kearah yang baik, nilai-nilai tersebut adalah: (1) nilai religius, (2) nilai jujur, (3) nilai toleransi, (4) nilai disiplin, (5) nilai kerja keras, (6) nilai kreatif, (7) nilai mandiri, (8) nilai demokratis, (9) nilai rasa ingin tau, (10) nilai semangat kebangsaan, (11) nilai cinta tanah air, (12) nilai menghargai peserta, (13) nilai komunikatif/bersahabat, (14) nilai cinta damai, (15) nilai gemar mebaca, (16) nilai peduli lingkungan, (17) nilai peduli sosial, (18) nilai tanggung jawab (Suyadi, 2013: 42).

\section{METODE PENELITIAN}

Penelitian ini akan dilaksanakan di Kelurahan Taubonto, Kecamatan Rarowatu, Kabupaten Bombana. Penelitian ini menggunakan penelitian deskritif kualitatif, dimana pada rumusan masalah pertama, kedua dan yang ketiga menggunakan penelitian deskritif kualitatif karena menyajikan data yang berupa kata-kata dan bahasa. Jenis penelitian sejarah yang bersifat deskriktif kualitatif ini juga menggunakan pendekatan yaitu pendekatan strukturis. Pendekatan strukturis yaitu mempelajari peristiwa dan struktur sebagai suatu kesatuan yang saling melengkapi. sedangkan sumber data yang digunakan dalam penelitian ini terdiri atas sumber tertulis, sumber lisan, sumber visual.

Prosedur yang digunakan dalam penelitian ini adalah metode sejarah sesuai pendapat Sjamsuddin (2016: 85). Heuristic yang terdiri dari penelitian Kepustakaan, yaitu penulis mencari data yang diperlukan mengenai sumber-sumber tertulis berupa buku-buku, skripsi dan sumbersumber lainnya yang relevan yang sesuai dengan judul dan masalah yang dikaji. Pengamatan, yaitu teknik pengumpulan data yang dilakukan dengan cara mengadakan pengamatan secara langsung terhadap kondisi dan keadaan yang akan diteliti. Wawancara, yakni penelitian mengadakan wawancara atau tanya jawab dengan beberapa informan yang dipercaya yang banyak mengetahui permasalahan yang diteliti sehingga dapat diperoleh data-data dan informasi yang dibutuhkan.

Verifikasi merupakan kritik terhadap sumber data untuk mendeskripsikan otentitas dan kredibilitas data yang telah terkumpul kemudian dilakukan analisis kritis sejarah baik secara kritik eksternal maupun kritik internal. Dan yang terakhir adalah historiografi yang terdiri atas penafsiran (Interpretasi) penjelasan (Eksplanasi) dan penyajian (Ekspose)

\section{HASIL PENELITIAN DAN PEMBAHASAN}

Latar Belakang Etnopedagogi Dalam Budaya Masyarakat Moronene Di Kelurahan Taubonto

Etnopedagogi adalah pembelajaran berbasis kearifan lokal yang tidak diperoleh dalam jenjang pendidikan formal, tetapi pendidikan berbasis kearifan lokal ini tumbuh, berkembang dan di 
ajarkan seara turun-temurun dalam lingkungan keluarga. Kearifan lokal ini merupakan gagasan yang muncul dan berkembang secara terus menerus dalam sebuah masyarakat berbentuk adatistiadat, budaya, sistem tatanan kehidupan, tata aturan/norma, keperayaan dan lain sebagainya (Arsad, 25 Desember 2018).

Pendidikan merupakan sebuah kebutuhan dasar kehidupan masyarakat modern saat ini. Pendidikan begitu penting dalam mengatasi pengaruh perkembangan zaman, begitu pula dengan pendidikan kearifan lokal dianggap sangat perlu karena telah banyak anak-anak saat ini yang mulai lupa akan identitas budayanya sendiri karenadipengaruhi oleh perkembangan zaman.

Pendidikan dalam masyarakat suku Moronene hampir sama dengan pendidikan yang ada pada suku-suku lainnya yang berada di wilayah sulawesi tenggarah yang mana dalam pendidikannya di ajarkan bagiamana menghargai orang yang lebih tua, sopan santun, kemandirian dan kerja keras. Menurut informan Abdul Arise (Wawancara, 27 Desember 2018) mengatakan bahwa: saya mempunyai 3 orang anak laki-laki, saya tidak perna memanjakan anak saya mulai dari dia masuk SD sampai kuliah. Ketika dia sudah pulang sekolah saya menyuruh mereka ke sawah untuk membantu saya, namun saya tidak memaksakannya untuk melakukanna. Selalu mengajari anak saya untuk selalu bekerja keras dan mandiri sejak dia kecil, seperti mencici piring, mencuci pakain serta membersikan rumah, meskipun mereka anak laki-laki tetap harus diajarkan hal-hal seperti itu karena tidak menuntut pekerjaan seorang perempuan di kerjakan oleh seorang laki-laki.

\section{Implementasi Etnopedagogi Dalam Lingkungan Keluarga Masyarakat Moronene Di Lingkungan Sekitarnya}

\section{a. Pendidikan dalam Bidang Keagamaan}

Dalam hal agama, Suku Moronene mayoritas beragama islam sebagaian lain memeluk agama kristen. Meskipun mereka sudah memeluk agama resmi, tetapi masih dijumpai unsur-unsur keperayaan dari nenek moyangnya atau leluhurnya. Unsur-unsur keperayaan itu biasanya munul dalam tradisi upacara adat, yang masih dilakukan dan dihubungkan dengan peristiwa-peristiwa sekitar lingkungan hidup individu, seperti pada acara Pinokompopinda Pali (dituntut untuk menginjak kapak), yang didalam terdapat makna simbolik bagi orang yang akan menjalani kehidupan baru setelah perkawinan (Ali Akbar, Wawancara 28 Desmber 2018). Senada dengan itu seorang informan mengatakan bahwa: aspek ini dikaitkan dengan agama dan keperayaan masyarakat tentang kepercayaan mengenai mahluk gaib atau mahluk halus dan roh-roh. Hal ini mendorong manusia untuk melakukan perbuatan-perbuatan yang dapat menghubungkan dirinya dengan ketentuan-ketentuan yang berada di atas dirinya. Puerson (1988:55) mengemukahkan bahwa dunia mistik terutama ditandai oleh rasa takut dalam diri manusia terhadap daya-daya purba dalam hidup dan alam raya (Jaz, Wawancara 28 Desember 2018).

Masyarakat Moronene disamping mempercayai adanya tuhan yang maha esa sebagai pencipta alam semesta juga mempercayai akan adanya kekuatan lain yakni roh-roh atau arwah para leluhur yang dapat menggangu aktivitas atau membawah malahpetaka bagi mereka jika ada perbuatan yang melanggar norma-norma yang ada dalam kehidupan masyarakat Moronene.

\section{b. Pendidikan dalam Bidang Bertata Krama}

Dalam kebudayaan Moronene ada yang disebut Moko Anu dan Upalli inilah yang membangun semangat manusia. Ketika ia tidak membawah pulang kesuksesan, merasa malu jika tidak berhasil dikampungnya orang, malu jika dihina dan sebagainya. Begitupun dalam budaya Upalli, Upalli merupakan salah satu larangan yang tidak bisa dilanggar, jika dilanggar maka akan terjadi bencana, misalnya seorang perempuan tidak boleh bernyanyi di dapur pada saat memasak karena Upalli, upallio ana ate ana dalo monahu dapura (pantang bagi anak gadis menyanyi di dapur) ( Maeng, Wawancara, 31 Desember 2018). Orang Moronene menjadikan pantang menyanyi di dapur pada anak gadis. Akibat yang dapat ditimbulkan dari pelanggaran itu adalah kemungkinan anak gadis tersebut mendapatkan jodoh orang yang sudah tua. Secara logika, tidak ada hubungan secara langsung antara menyanyi di dapur dengan jodoh seseorang. Memasak adalah aktivitas manusia sedangkan jodoh adalah takdir, nasib, dan kehendak Allah SWT. 


\section{c. Pendidikan dalam Bidang Bertutur Kata}

Bertutur kata adalah sesuatu yang kita ucapkan dengan baik dan santun. Serta mencerminkan tingkah laku yang menimbulkan kepercayaan kepada orang lain, ketika sedang berbicara dengan sesamanya. Contoh pemakain bahasa moronene yang sopan dan yang sering digunakan sehari-hari yaitu" Mongkamo sala (makan mi dulu)". "Hapa da'ni weweu'u (apa yang sedang dilakukan)". "Totoromo (silahkan duduk)". "Nta lako akumo sala (permisi saya pergi dulu)".

Salah seorang informan mengatakan bahwa pada saat saya hamil saya selalu meminta kepada Allah agar diberikan anak yang berguna dan bermanfaat bagi masyarakat dan negara, anak yang bisa menjaga nama baik keluarganya. Pada saat anak saya beusia 4-7 tahun, saya sudah mulai mengajarkan mereka berbicara, berjalan, mengaji, sholat serta mengajari bagaimana menghargai orang yang lebih tua darinya, dan sopan santun seperti Tabea (permisi) sambil membungkukan setengah badannya bila melewati orang tua yang sedang bercerita. Mereka harus mengetahui budayanya sejak kecil dan menerapkan sejak kecil agar kelak ketika mereka jauh dari keluarga mereka tidak akan lupa dan selalu mengingat dan berpegang teguh pada budayanya karena kebiasan-kebiasannya yang baik yang sering diajarkan sejak masih kecil (Ismi Hariyanti, Wawanara, 01 Januari 2019).

\section{d. Pendidikan dalam Bidang Sosial}

Masyarakat Moronene dalam kehidupan sosialnya hampir sama dengan suku-suku lainya yang berada di wilayah daratan sulawesi tenggara yang mana dalam kehidupan sosialnya mengenal istilah gotong royong, implementasi kegiatan gotong royong dalam kehidupan sosial masyarakat suku Moronene terdapat dalam berbagai bidang, salah satunya, dalam prosesi pernikahan.

Masyarakat Moronene mengenal istilah motimba langa (mengumpulkan mahar). Mengumpulkan mahar ini dilakukan oleh masyarakat untuk membantu keluarga pihak mempelai laki-laki dalam hal pemenuhan mahar (langa) adat sesuai yang diminta dari pihak keluarga mempelai perempuan. Dalam pelaksanaan motimba langa ini tidak ada paksaan atau patokan apaapa saja yang orang-orang akan sumbangkan kepada pihak keluarga mempelai laki-laki semua diberikan secara suka rela. Proses ini dilakukan oleh semua orang tidak memandang status sosialnya baik dia dari golongan ekonomi menengah keatas maupun menengah kebawah tanpa terkecuali meskipun dia keturunan bangsawan maupun dari golongan masyarakat biasa, prosesi motimba langa ini tidak bisa untuk tidak dikerjakan karena prosesi ini masuk dalam rangkaian upacara adat pernikahan pada masyarakat Moronene. Adapun hal-hal yang disumbangkan dalam prosesi ini bisa berupa benda adat atau dinominalkan dalam sejumlah uang.

\section{Karakter Yang Dikembangkan Pada Etnopedagogi Dalam Budaya Masyarakat Moronene}

Karakter yang dikembangkan dalam budaya masyarakat Moronene itu sama dengan karakter dari suku-suku lainnya, masyarakat suku Moronene memiliki karakter yang sangat khas dan kental. Karakter orang moronene adalah baik, ramah, tidak kasar, suka menolong, dan menerimah orang baru.

Adapun karakter yang masih dipegang teguh masyarakat moronene samapai sekarang yaitu:

\section{Kejujuran}

Jika ingin melihat pandangan hidup anak-anak maka kita akan menguji dia, menguji dengan cara baik. Saya selalu menguji anak saya dengan cara meletakan uang di sembarang tempat, namun ternya meskipun saya meletakan uang di sembarang tempat satu persen pun anak saya tidak ada yang mengambilnya, jangan mengambil menyentuhnya pun dia takut, di sini dapat terlihat nilai-nilai kejujuran yang tertanam dalam hati anak saya. Saya memang senantiasa mengajarkan kepada anak saya bahwa tidak boleh mengambil barang oang lain yang bukan milik kita sendiri (Erni, Wawancara, 07 Januari 2019).

Di dalam mayarakat Moronene, dalam berbagai konteks kejujuran kata ini juga bermakna, ikhlas, benar, baik atau adil. Sedangkan kata lawannya adalah culas, curang, dusta, khianat, buruk dan menipu. Kejujuran atau pandangan hidup seorang anak dapat terpancar lewat tingkah lakunya. 
Sebagian orang tua ketika ingin melihat sejauh mana seorang anak memahami yang namanya budaya malu yang telah diajarkan orang tuanya, orang tua akan mengujinya. Lewat ujian inilah pandangan hidup seorang anak, akan terlihat dan terpancar lewat tingkahlaku dan kejujurannya baik kepada keluarganya maupun masyarakat yang ada di sekitarnya.

\section{Disiplin}

Disiplin adalah rasa taat dan patuh terhadap nilai yang diberikan orang tua kepada anaknya. Sebagai orang tua tidak lupa untuk mengajari anaknya mengenai kedisiplinan, karena disiplin itu merupakan sikap yang selalu tepat janji, sehingga orang tua memberikan kepercayaan kepada anaknya. Orang tua biasanya mengajari anaknya tentang kedisiplinan dalam mengunakan waktu, kedisiplinan dalam beribadah (Nurlia, Wawancara, 10 Januari 2019).

Senada dengan itu seorang informan mengatkan bahwa: saya mengajari anak saya mengenai kedisiplinan agar ia dapat mengetahui bagaimana menghargai waktu, peduli terhadap sesamanya, menumbuhkan ketenangan terhadap dirinya, serta membantu perkembangan otaknya. Mengajari anak tentang kedisiplinan bukan hanya untuk menghargai waktu dan lain sebagainya, tetapi anak juga bisa mrengetahui bagaiamana disiplin untuk diri sendiri dan disiplin sosial (Ihsan, Wawancara, 10 Januari 2018).

\section{Kemandirian}

Setia orang tua di masyarakat Moronene mendidik anaknya begitu ketat sehingga mampu belajar mandiri itu dapat membuat kita sadar akan kemampuan yang ada dalam dirinya sendiri seperti, kemampuan mengerjakan tugas yang dipertanggung jawabkan kepadanya, kemampuan mengatasi rintangan yang dihadapi dalam mencapai suatu kesuksesan, kemampuan untuk selalu bertindak jujur dan benar sesuai hak dan kewajiban, serta selalau membantu orang atau melakukan tindakan yang bermanfaat bagi orang lain dan lingkungannya. Kemandirian adalah sikap yang memungkinkan seseorang untuk bertindak bebas, dan bermanfaat, berusaha melakukan segala sesuatu dengan jujur dan benar atas dorongan dirinya sendiri dan kemampuan mengatur diri sendiri, sesuai dengan hak dan kewajibannya, sehingga dapat menyelesaikan masalah-masalah yang dihadapinya.

\section{Demokratis}

Orang tua juga selalu memberikan bimbingan dan arahan yang penuh perhatian terhadap anak mana yang boleh dilakukan dan mana yang tidak boleh dilakukan. Hal tersebut dilakukan orang tua dengan lemah lembut dan penuh kasih sayang. Nilai demokrasi ini ditandai dengan adanya sikap terbuka antara orang tua dan anak, mereka mebuat aturan-aturan yang disetujui bersama. Anak diberikan kebebasan untuk mengemukakan penapat, perasaan dan keinginannya. Jadi didalam demkratis ini harus terdapat komunikasi yang baik antara orang tua.

Nilai demokratis merupaka cara mendidik anak dimana orang tua menetukan peraturanperaturan tetapi dengan memperhatikan keadaan dan kebutuhan anak (Munandar, 1982: 98) nilai demokratis adalah suatu bentuk yang memperhatikan dan menghargai kebebasan anak, namun kebebasan itu tidak mutlak dan dengan bimbingan yang penuh pengertian antara orang tua dan anak.

\section{Tanggung Jawab}

Dalam keluarga masyarakat moronene secara kodratnya terdapat pembagian tugas, tanggung jawab dan fungsi-fungsinya. Bapak memimpin keluarga, ia bertanggung jawab sepenuhnya dalam lingkungan keluarga, oleh karena itu kedudukannya sangat menentukan. Akan tetapi seorang ibu juga mempunyai tugas, tanggung jawab serta fungsi-fungsinya tertentu. Sehubungan dengan itu dalam menyelanggarakan kehidupan keluarga harus menciptakan keharmonisan dan keserasian antara anggota keluarga sehingga menciptakan keluarga yang sejatrah lahir dan batin. Bahkan anak juga mempunyai tanggung jawab kepada orang tua dikerenakan ia sudah dewasa sudah bisa membedakan mana yang baik dan mana yang buruk. Sehingga tanggung jawab yang diberikan juga tidak terlalu memberatkan anak, sebab jika telalu berat tanggung jawab yang diberikan kepada anak biasanya berdampak buruk. Tanggung jawab yang umum biasanya diberikan orang tua kepada anaknya yang beranjak dewasa yaitu menjaga dirinya, mendidik adiknya, menjadi contoh yang baik untuk adiknya ketika orang tuanya lagi pergi merantau atau 
keluar kota. Hal-hal kecil seperti itulah yang orang tua pada masyarakat moronene ajarkan kepada anaknya sehingga kelak ia dewasa bisa mengurus rumah tangganya sendiri dengan baik.

\section{PENUTUP}

Latar belakang etnopedagogi dalam budaya masyarakat moronene, etnopedagogi merupakan landasan dalam pendidikan sejalan dengan salah satu landasan filosofi pengembangan pendidikan yang berakar pada budaya bangsa masa kini dan masa yang akan dating. Istilah etnopedagogi terdiri dari dua suku kata, yaitu ento (dari kata etnik) artinya suku bangsa dan pedagogi artinya ilmu pendidikan, maka etnopedagogi berarti nilai-nilai yang ada pada setiap suku bangsa. Pendidikan yang berbasis kearifan lokal ada apa masyarakat moronene lahir karena adanya kesadaraan masyarakat tentang pentingnya melestarikan tradisi yang ada pada masyarakat moronene secara turun temurun. Tradisis yang masih dilestarikan dan diajarkan secara turun temurun masyarakat moronene samapai saat ini yaitu Kada. Implementasi etnopedagogi dalam lingkungan masyarakat moronene yaitu: (a) Pendidikan dalam bidang agama. Dalam hal agama suku moronene mayoritas agama islam dan lainnya memeluk agama Kristen. (b) Pendidikan dalam bidang bertata karma, dalam budaya masyarakat moronene ada yang disebut Moko Anu dan Upalli inlah yang membangun semangat manusia ketika ia pergi untuk menuntut ilmu maupun bekerja. (c) Pendidkan dalam bidang bertutur kata, bertutur kata adalah sesuatu yang kita ucapakan dengan baik dan santun, serta mencerminkan tingkahlaku yang menimbulkan kepercayaan kepada orang lain, ketika sedang berbicara dengan sesamanya. (d) Pendidikan dalam bidang kehidupan sosial, masyarakat mornene dalam kehidupan sosialnya hamper sama dengan suku-suku lainnya yang berada di dataran Sulawesi tenggara, yang mana dalam kehidupannya sehari-hari mengenal yang namanya istilah gotong royong. Karakter yang dikembangkan pada etnopedagogi dalam budaya masyarakat moronene, karakter yang dikembangkan yaitu: (1) Kejujuran, dimana anak sejak masih kecil sudah mulai diajarkan jujur kepada orang tuanya. (2) Disiplin, anak sejak masih kecil sudah mulai diajarkan disipiln waktu. (3) kemandirian, anak dia ajarkan mandiri agar dapat mengurus dirinya sendiri. (4) Demokratis, ini ditandai dengan adanya sikap terbuka antara orang tua dan anak. (5) Tanggung jawab, tanggung jawab keluarga merupakan pusat pendidikan tidak hanya menyelenggarakan pendidikan diri dan sosial.

\section{DAFTAR PUSTAKA}

Arif, Muhammad. 2011. Pengantar Kajian Sejarah. Bandung: Yrama Widya.

Hafid, Anwar dkk. 2014. Konsep Dasar Ilmu Pendidikan. Alfabeta : Bandung

Hafid, Anwar. 2017. Pengembangan Pembelajaran Sejarah Berbasis Etnopedagogi. Himpunan Serjana Pendidikan Ilmu-Ilmu Sosial: Kendari.

Kartodirjo, Sartono. 2017. Pendekatan Ilmu Sosial Dalam Metodologi Sejarah. Yogyakarta: Ombak.

Munandar, Soelaeman M. 1989. Ilmu Budaya Suatu Pengantar. Bandung: Eresco.

Nawili. 2015. Kajian Kearifan Local Kelompok Budaya Dani Lembah Baliem Wamena Papua.

Jurnal: Pendidikan Nasional Nusantara Indonesia. (Vol. 1. No.1). Halaman 14.

Pelly, Theodorson, 1994. Ilmu Budaya Dasar. Tengerang Selatan: Jelaja Nusa.

Permen No. 9 Tahun 2013. Pendidikan Berakar pada Budaya Bangsa Masa Kini dan Masa Yang Akan Datang. Yogyakarta: Ombak.

Rohman, Arif. 2013. Memahami Ilmu Pendidikan. Yogyakarta: Aswaja.

Salam, Burhanuddin. 2002. Pengantar Pedagogik (Dasar-Dasar Ilmu Mendidik). Jakarta: Rineka Cipta.

Setiadi, Elly M., dkk. 2009. potensi masyarat terhadap lingkungan.jakarta. Elangga.

Sunny. 2013. Teori Pendidikan Dan Teknologi. Akses Tanggal 30 Desember 2018.

Suyadi. 2013. Strategi Pembelajaran Pendidikan Karakter. Bandung: Remaja Rosdakarya.

Sjamsuddin, Helius. 2016. Metodologi Sejarah. Yogyakarta: Ombak.

Syarbani, Syahrial. 2009. Dasar-Dasar Psikologi. Bandung: Graha Ilmu. 